\title{
Research on the Relationship between Earnings Management and Business Performance of Commercial Banks
}

\author{
Yayuan Ji \\ School of Management, Wuhan University of Technology, Wuhan,P.R.China \\ 734412306@qq.com
}

Keywords: Commercial banks; Earnings management; Business performance; Modified Jones model

\begin{abstract}
With the vigorous development of China's market economy, competition among commercial banks has become increasingly fierce. The operation of commercial banks is experiencing different levels of earnings management. Based on 16 Chinese listed commercial banks from 2012 to 2017, this paper first calculates the operating profit based on the Jones model, and then empirically tests that there is a significant negative correlation between commercial bank earnings management and economic performance. The higher the degree of earnings management of commercial banks, the worse the business performance. Based on recent business data and empirical research results, this paper establishes measurement indicators and models for four aspects of enterprise performance, and uses correlation analysis and regression analysis to study its operation. By studying the earnings management of listed commercial banks under different circumstances, this paper puts forward reasonable suggestions for China's listed commercial banks, and provides a reference for improving their own corporate value.
\end{abstract}

\section{Introduction}

At this stage, poor earnings management is the most important reason for the distortion of accounting information of commercial banks in China, and it also hinders the growth of its business performance. There is indeed a correlation between earnings management and business performance. Based on the existing literature, there are few research theories on earnings management for commercial banks. Therefore, the correlation between the management of commercial banks' earnings management and business performance is significant in both theory and reality. Based on the empirical research results at home and abroad, this paper establishes the measurement indicators from the four aspects of profitability, operational capability, solvency and growth ability, and builds a model to finance the listed commercial banks in recent years. Based on the report data, the two empirical methods of correlation analysis and regression analysis are used to analyze the degree of earnings management of listed commercial banks under different operating conditions, and then make reasonable suggestions for listed commercial banks in China.

\section{Overview of Earnings Management and Business Performance}

How to effectively and correctly conduct appropriate earnings management in different situations has now become a new topic that is widely discussed in the financial community.

Earnings Management. Earnings management is a behavior that the listed commercial banks use some accounting methods or the planning of real transactions to change the financial report within the scope permitted by accounting standards and accounting systems, thereby affecting the judgment of stakeholders on the company's performance, so that listed commercial banks can obtain some interest long-term accounting behaviors.

In empirical research, the use of manipulated profits as a surrogate variable in the level of earnings management has yielded a series of results. Before the empirical analysis of earnings management methods, this paper also based on the basic Jones model for the calculation of manipulable profits as follows: 
$T A C_{\mathrm{j}, t}=E_{j, t}-C F O_{j, t}$

Among them: $T A C_{j, t}$ is the total accrued profit of the $\mathrm{t}$-th period of the $\mathrm{j}$-th commercial bank; $E_{j, t}$ is the net profit of the $\mathrm{t}$-th period of the $\mathrm{j}$-th commercial bank; $C F O_{j, t}$ is the net cash flow generated by the business activity of the $t$-th period of the $j$-th commercial bank.

The following formula Eq.2 is regressed according to different years, and the regression coefficient of formula Eq. 2 is substituted for formula Eq.3 to obtain the non-manipulable profit NDTAC.

$$
\begin{aligned}
& T A C_{j, t} / T A_{j, t-1}=a_{0}+a_{1}\left(1 / T A_{j, t-1}\right)+a_{2}\left(\Delta R E V_{j, t-1} / T A_{j, t}\right)+a_{3}\left(P P E_{j, t} / T A_{j, t-1}\right)+\varepsilon_{j, t} \\
& N D A_{j, t} / T A_{j, t-1}=a_{0}+a_{1}\left(1 / T A_{j, t-1}\right)+a_{2}\left(\Delta R E V_{j, t}-\Delta R E C_{j, t}\right) / T A_{j, t-1}+a_{3}\left(P P E_{j, t} / T A_{j, t-1}\right)
\end{aligned}
$$

$N D A_{j, t}$ is the non-manipulable profit of the $\mathrm{t}$-term of the $\mathrm{j}$-th commercial banks, $\triangle R E V_{j, t}$ is the difference between the income of the main business of the $\mathrm{t}$-th business of the $\mathrm{j}$-th commercial bank and the income of the main business of the previous year, $\triangle R E C_{j, t}$ is the current period of the commercial bank t-term, the difference between the accounts receivable at the end of the period and the accounts receivable at the end of the previous period, $P P E_{j, t}$ is the net fixed assets at the end of the t period of the $\mathrm{j}$-th commercial bank, and $T A_{j, t}$ is the total assets at the end of the $\mathrm{t}-1$ period of the $\mathrm{j}$-th commercial bank.

$$
D A_{j, t} / T A_{j, t}=T A C_{j, t} / T A_{j, t-1}-N D A_{j, t} / T A_{j, t-1}
$$

$D A_{j, t} / T A_{j, t}$ is a manipulative profit adjusted by total assets. It is a very important indicator in the measure of earnings management. In the subsequent empirical process of this paper, this indicator will be used as a dependent variable to measure earnings management.[1]

Business performance. In general, the company's business performance can be analyzed from the following four levels, and commercial banks are no exception. The first level, profitability, ROE are indicators of how a company uses its investment to generate profit growth. The second level, solvency, asset-liability ratio is a reflection of the proportion of debt financing in total assets, which can be used to measure the protection of creditors' interests in the process of corporate liquidation.The third level, operational capability, and total asset turnover is a comprehensive assessment of the operational capabilities of all of the company's assets. The fourth level, growth ability, commercial bank's growth ability and net profit growth rate in the same direction. The main business income growth rate measures the growth ability of the enterprise and can judge the development stage of the enterprise.

Relationship between earnings management and business performance. The ST and delisting mechanisms in China's securities market force listed companies to increase their value through earnings management, thereby achieving profitability. One of the main purposes of earnings management is to whitewash financial reports. Therefore, it is generally believed that the worse the level of business performance, the greater the incentive for enterprises to conduct earnings management behavior, and the deeper the degree of earnings management of enterprises.

\section{Research on Earnings Management and Business Performance}

Through the existing scholars' research on business performance of earnings management, it shows that business performance has a certain degree of impact on the earnings management of commercial banks, mainly earnings management and return on net assets, asset-liability ratio, total asset turnover, and net profit growth., and the growth rate of the main business income, the specific situation is as follows.

Earnings Management and Return on Net Assets. Ai Lin and Cao Guohua (2013) research evidence shows that the degree of earnings management of commercial banks may also be intensified. Earnings management behavior is harmful and will reduce business performance.[2] 
Earnings management and asset-liability ratio. Deng Xueya, Jiang Wei, Wu Yanhong (2013) showed that the operational profit reflected in the income statement is directly affected by the asset-liability ratio. The bank's current manipulable profit account title will be positively affected by the balance sheet account title. The bank debt account title and amount title are expressed in the income statement accounting subjects and the amount, which can keep the net profit achieved in each year stable.[3]

Relationship between earnings management and total asset turnover. Wu Keping and $\mathrm{Yu}$ Fusheng (2013) pointed out that the ratio of the net income of the main business to the average total assets of a bank in a certain period of time can reflect the utilization rate of all assets. The higher the turnover rate, the faster the sales rate of commercial banks is. The turnover rate will inevitably directly affect the manipulable profits of commercial banks.

Relationship between earnings management and net profit growth rate. Generally speaking, a sound accounting principle will ensure that the qualified growth of net profit will lead to a direct increase in operational profit and ensure the stable operation of the company. In the report, Yang Qingli, chief analyst of the financial industry, analyzed that the asset quality of Shenzhen Development Bank was the worst among listed banks.

Relationship between earnings management and revenue growth of main business. The main business income is the most basic management requirement of finance. With the help of earnings management, after the connection between the real economy and the information economy, the "amplification effect" may occur in information transmission and feedback, resulting in passive management or out of control, which affects the future development of the enterprise.

\section{Empirical Analysis of the Relationship between Earnings Management Level and Business Performance of Commercial Banks}

Selection of variables. From the perspective of the company's corporate earnings management, this paper comprehensively evaluates the performance level of the company from four aspects: corporate profitability, corporate debt repayment, business operation and business growth.

The first aspect selects the return on net assets. The greater the value of the return on net assets, the stronger the profitability of the enterprise. ; The second aspect selects the indicator of asset-liability ratio, because the more corporate liabilities, the more profitability and development capacity will be affected, and the more likely the enterprise is to conduct earnings management operations; The third aspect selects the total asset turnover rate. Because the assets of large-scale commercial banks operate frequently, the total assets change significantly in the short term, but may be the result of artificially controlling the surplus; The fourth aspect selects the net profit growth rate and the main business income growth rate. The net profit growth rate represents the pure profit level and development potential of the enterprise. The better the business performance of the enterprise in the current year, the greater the net profit growth rate. The future growth ability is more worthy of expectation. The general scholar believes that if the current main business growth rate of the enterprise exceeds $10 \%$, the next growth ability at the best level, so we bring these five variables as independent variables into the model.[5]

The earnings management variable calculated according to the Jones model can control the profit DA, and divide the DA by the total assets at the beginning of the sample bank. Then the absolute value of the ratio is named DARS, and the indicator is used to measure the degree of earnings management of the listed company. Use it as an dependant variable construct the research model of earnings management level and performance of listed commercial banks in China to conduct empirical research. 
Table 1 Variable name definition and calculation method

\begin{tabular}{|c|c|c|}
\hline Name & variable & calculation method \\
\hline Manipulable profit ratio & DARS & is calculated from the modified Jones model \\
\hline Return on equity & ROE & net profit / average balance of shareholders' equity \\
\hline Asset-liability ratio & LEV & Total liabilities / total assets \\
\hline Total Asset Turnover & TDA & Operating Income / Total Assets \\
\hline Net profit growth rate & GR1 & (net profit this year - net profit last year) / net profit last year \\
\hline $\begin{array}{l}\text { Main business income } \\
\text { growth rate }\end{array}$ & GR2 & $\begin{array}{c}\text { (main business income of the year - main business income last year) / } \\
\text { main business income last year }\end{array}$ \\
\hline
\end{tabular}

Sample selection and data source. This paper selects the earnings management data and financial performance data of 16 early established and large commercial banks as model variables to construct relevant research models. Financial related data mainly comes from the CSMAR database and the giant tide network database. The empirical analysis of this paper mainly uses SPSS and EXCEL to carry out the main model architecture.[6][7]

Hypothesis. Combined with the research status of other scholars, this paper proposes the following hypothesis:

Table 2 Hypotheses

\begin{tabular}{|c|l|}
\hline $\begin{array}{c}\text { Hypothesis } \\
\text { one }\end{array}$ & $\begin{array}{l}\text { H0: There is no correlation between the degree of management of the bank's earnings and the } \\
\text { profitability of the company }\end{array}$ \\
\cline { 2 - 3 } & $\begin{array}{l}\text { H1: There is a negative correlation between the degree of management of the bank's earnings and } \\
\text { the profitability of the company }\end{array}$ \\
\hline $\begin{array}{c}\text { Hypothesis } \\
\text { two }\end{array}$ & $\begin{array}{l}\text { H0: There is no correlation between the degree of management of the bank's earnings and the debt } \\
\text { situation of the company }\end{array}$ \\
\cline { 2 - 3 } $\begin{array}{l}\text { H1: There is a positive correlation between the degree of management of the bank's earnings and } \\
\text { the debt situation of the company }\end{array}$ \\
\hline $\begin{array}{c}\text { Hypothesis } \\
\text { three }\end{array}$ & $\begin{array}{l}\text { H0: There is no correlation between the degree of management of the bank's earnings and the } \\
\text { operation of the company }\end{array}$ \\
\cline { 2 - 3 } $\begin{array}{c}\text { Hypothesis } \\
\text { four } \\
\text { the operation of the company }\end{array}$ & $\begin{array}{l}\text { H0: There is no correlation between the degree of management of the bank's earnings and the } \\
\text { growth of the company }\end{array}$ \\
\cline { 2 - 3 } & $\begin{array}{l}\text { H1: There is a negative correlation between the degree of management of the bank's earnings and } \\
\text { the growth of the company }\end{array}$ \\
\hline
\end{tabular}

Design of the research model. According to the variables listed above, we can construct a multivariate regression model related to the earnings management level of China's commercial banks and business performance, such as formula Ep.5.

$$
D A R S=\beta_{0}+\beta_{1} R O E+\beta_{2} L E V+\beta_{3} T D A+\beta_{4} G R 1+\beta_{5} G R 2
$$

DARS is the dependent variable, $\beta_{0}$ is a constant term, and $\beta_{1}, \beta_{2}, \beta_{3}, \beta_{4}$, and $\beta_{5}$ are the coefficients to be estimated.

\section{Empirical research results and analysis.}

Table 3 Correlation Analysis of Earnings Management and Business Performance of China's Listed Commercial Banks

\begin{tabular}{|c|c|c|r|r|r|r|}
\hline & Earnings Management & ROE & LEV & TDA & GR1 & GR2 \\
\hline DARS & 1 & & & & & \\
\hline ROE & $-0.322^{*}$ & 1 & & & & \\
\hline LEV & $0.313^{*}$ & $0.407^{* *}$ & 1 & & & \\
\hline TDA & $0.716^{* *}$ & -0.106 & $0.318^{*}$ & 1 & & \\
\hline GR1 & $-0.466^{* *}$ & $0.376^{* *}$ & 0.162 & -0.213 & 1 & $*$ \\
\hline GR2 & $-0.416^{* *}$ & 0.121 & -0.191 & -0.028 & $0.356^{*}$ & 1 \\
\hline
\end{tabular}

* . represents a significant correlation at the 0.05 level (both sides).

**. represents a significant correlation at the 0.01 level (both sides).

By observing and comparing the above values and analyzing the correlation between earnings management and various variables, it can be seen that the earnings management level variable and 
the return on net assets are significantly negatively correlated at the level of 0.05 , and there is a strong negative correlation between the two.The correlation coefficient between earnings management and asset-liability ratio is positive, and there is a significant positive correlation between the two. Both earnings management and total asset turnover were significantly positively correlated at the level of 0.01. Earnings management and net profit growth rate and main business income growth rate were significantly negatively correlated at the level of 0.01 . Through the correlation analysis, the relationship between the earnings management level of China's listed commercial banks and their performance is preliminarily judged, but further analysis is needed by regression analysis.[8]

Table 4 Regression Analysis of Earnings Management and Business Performance of Commercial Banks

\begin{tabular}{|c|c|c|c|c|c|}
\hline \multirow{2}{*}{ model } & \multicolumn{2}{|c|}{ Non-standardized coefficient } & $\begin{array}{c}\text { standardized } \\
\text { coefficient }\end{array}$ & \multirow{2}{*}{$\mathrm{t}$} & \multirow{2}{*}{ sig.. } \\
\cline { 2 - 5 } & $\mathrm{B}$ & Standard error & trial version & & \\
\hline (constant) & -14.266 & 5.888 & & -2.423 & $0.020^{*}$ \\
\hline ROE & -4.871 & 1.853 & -0.241 & -2.629 & $0.012^{*}$ \\
\hline LEV & 14.207 & 6.610 & 0.209 & 2.149 & $0.037^{*}$ \\
\hline TDA & 81.545 & 12.391 & 0.575 & 6.581 & $0.000^{* *}$ \\
\hline GR1 & -1.246 & 0.589 & -0.194 & -2.116 & $0.040^{*}$ \\
\hline GR2 & -1.262 & 0.420 & -0.261 & -3.003 & $0.004^{* *}$ \\
\hline R $^{2}$ & \multicolumn{7}{|c|}{0.725} & & $0.000^{\text {a }}$ \\
\hline F & 25.736 & sig. \\
\hline
\end{tabular}

* . represents a significant correlation at the 0.05 level (both sides).

**. represents a significant correlation at the 0.01 level (both sides).

As can be seen from the above table, the goodness of fit of the overall model is at a good level, and we believe that the strength of this solution is sufficient as data support for case demonstration. Looking up the table, it can be seen that the specific observations of the F-test statistics fall within the critical point, and there is a sequence correlation between the variables of the model. The probability significance level corresponding to the $\mathrm{F}$ test is less than the significance level of 0.05 , and the null hypothesis of the regression equation significance test should be rejected. The linear relationship between the dependent variable and the independent variable is significant. In addition, we set the criterion for the significance level value to 0.05. By comparison, it is found that there is a significant negative correlation between the return on net assets and the level of earnings management. Generally speaking, the stronger the ability of profitable enterprises to confront financial distress and financial crisis, the less the need for human intervention in earnings management, so the degree of earnings management is inevitable. Hypothesis 1 is the degree of earnings management of commercial banks and the profitability of enterprises. The inverse ratio has been proved.From the above table, LEV is significantly positively correlated with earnings management. Companies with higher debt ratios are more likely to conduct real earnings management activities because of creditor pressure and debt burden, and often convey false financial good information by artificially increasing the controllable accruals. Hypothesis 2 that the degree of earnings management of commercial banks is directly proportional to the debt situation of enterprises.[9]

It can be seen from the above table that TDA is significantly positively correlated with the level of earnings management. The total assets of China's large-scale commercial banks tend to be less volatile at a short-term point in time. Therefore, once the total asset turnover rate of commercial banks rises sharply, it indicates that there are exception factors that lead to the possibility of artificial surplus management.hypothesis 3 that the degree of earnings management of commercial banks is directly proportional to the operational capacity of enterprises.From the above table, it can be found that both GR1 and GR2 have a significant negative correlation with earnings management surplus. If the company has strong growth ability, it will attract investors and risk capital attention. 
If the company itself has strong potential, it will not need to carry out risky and costly earnings management operations to get the required operating environment. Therefore, hypothesis 4 that the degree of earnings management of commercial banks is inversely proportional to the growth ability of enterprises.[10]

We have substituted the regression coefficients we have obtained above into the research model of earnings management and business performance listed above, and obtained the empirical results of this paper, such as formula Ep.6.

$D A R S=-14.266-4.871 R O E+14.207 L E V+81.545 T D A-1.246 G R 1-1.262 G R 2$

\section{Summary}

The results obtained from the analysis of this paper show that the stronger the profitability and growth ability of commercial banks, the smaller the degree of earnings management, the more liabilities, and the higher the total asset turnover rate. The deeper the management of earnings of commercial banks.

With the increase in the number of commercial banks listed, the degree of competition will deepen, and whether the degree of earnings management of commercial banks will also intensify, it should also be a matter of further concern. Through earnings management, it seems that it has established a good business image. In fact, it poses a certain threat to the actual operation of commercial banks and long-term benign development. Commercial banks conduct earnings management by reducing the balance of non-performing loans to present good financial statement information. However, in fact, non-performing loans still exist after the management of earnings management, which adversely affects the development of commercial banks and reduces the profit development space of commercial banks.

All in all, the management of earnings in commercial banks is a double-edged sword. In the operation of commercial banks, it is necessary to use earnings management reasonably, and to improve some possible improper earnings management, in order to promote the healthy development of commercial banks and effectively improve the business performance.

\section{References}

[1] X.Y.Li:The impact of the capital structure of listed commercial banks on business performance(MS.Lanzhou Jiaotong University,China 2014)(In Chinese)

[2] L.Ai, G.H.Cao: Management World, Vol. 29 (2013) No.11,p.174

[3] X.Y.Deng, X.Jiang and Y.H.Wu: Commercial Accounting, Vol. 34 (2013) No.13,p.69

[4] K.P.Wu, F.S.Yu: Journal of Shanxi University of Finance and Economics, Vol.34 (2013) No.2,p.96

[5] Y.J.Liu:Empirical test of the manipulative accrual profit model for the degree of earnings management(MS.Xinjiang University of Finance and Economics,China 2014)(In Chinese)

[6] Information on http://www.cninfo.com.cn/cninfo-new/index

[7] Information on http://us.gtadata.com/Home

[8] C.X.Fang:Research on real earnings management before and after IPO of listed companies in China(MS.Chongqing Jiaotong University,China 2013)(In Chinese)

[9] Q.Li, L.L.Yan: Journal of Xihua University, Vol. 33 (2014) No.1,p.62

[10] G.Q.Ma, Y.Han: Journal of Nanjing Audit University, Vol. 14 (2017) No.5,p.35 